\title{
Target Users' Expectations versus the Actual Compilation of a Shona Children's Dictionary
}

\author{
Esau Mangoya, African Languages Research Institute, University of \\ Zimbabwe, Harare, Zimbabwe (emangoya@arts.uz.ac.zw)
}

\begin{abstract}
The article discusses the challenges that confronted the team of compilers working on the monolingual Shona Children's Dictionary (henceforth SCD). It looks at the active involvement of the target users in shaping the project and discusses the considerations for the implementation of their recommendations. Matters of concern include issues of headword selection, especially problems of dialect representation in the dictionary. The article also discusses the inclusion of grammatical information such as tone marking. The SCD is one of the many efforts to promote and raise the functions of the indigenous languages in Zimbabwe. Of special interest in this article is therefore the discussion on the inclusion of international words like those denoting weight, distance and mathematical and scientific concepts. The article also considers the treatment of taboo words in the SCD, which takes into account that society has to open up culturally to be able to unequivocally view some of the aspects of life with which present-day children are confronted. The article lastly discusses how a balance was reached for accommodating the target users' proposal for the inclusion of an elaborate back matter in view of the limited available scope and space of the SCD.
\end{abstract}

Keywords: TARGET USERS, DIALECT REPRESENTATION, INTERNATIONAL WORDS, TABOO WORDS, TONE MARKING, BACK MATTER, DICTIONARY, LEXICOGRAPHY

Opsomming: Teikengebruikers se verwagtinge teenoor die werklike samestelling van 'n Sjonakinderwoordeboek. Die artikel bespreek die uitdagings waarvoor die span samestellers te staan gekom het tydens werk aan die eentalige Sjonakinderwoordeboek (voortaan SKW). Dit kyk na die aktiewe betrokkenheid van die teikengebruikers by die ontwikkeling van die projek en bespreek die oorwegings vir die uitvoering van hulle aanbevelings. Sake van belang sluit in kwessies van trefwoordkeuse, veral probleme van dialekverteenwoordiging in die woordeboek. Die artikel bespreek ook die insluiting van grammatiese inligting soos toonaanduiding. Die SKW is een van die baie pogings om die funksies van die inheemse tale in Zimbabwe te bevorder en te vergroot. Van spesiale belang in hierdie artikel is dus die bespreking oor die insluiting van internasionale woorde soos dié wat gewig, afstand en wiskundige en wetenskaplike konsepte benoem. Die artikel beskou ook die behandeling van taboewoorde in die SKW wat in aanmerking neem dat die gemeenskap kultureel oper moet word om in staat te wees om sommige aspekte van die lewe waarvoor hedendaagse kinders te staan kom, onomwonde te beskou. Laastens bespreek die artikel hoe ' $n$ balans verkry is om die teikengebruikers se voorstel vir die insluiting van ' $n$ uitvoerige agterwerk in te pas in ooreenstemming met die beperkte beskikbare omvang en ruimte van die SKW. 
Sleutelwoorde: TEIKENGEBRUIKERS, DIALEKVERTEENWOORDIGING, INTERNASIONALE WOORDE, TABOEWOORDE, TOONAANDUIDING, AGTERWERK, WOORDEBOEK, LEKSIKOGRAFIE

\section{Introduction}

A team of three people at the University of Zimbabwe's African Languages Research Institute (ALRI) embarked on a pioneering project to compile a monolingual Shona Children's Dictionary (henceforth SCD) whose main target users are school children at primary level. This team worked closely with teachers and parents who automatically became an interested party in the dictionary project, consequently constituting the majority of the target users. The project started in 2002 and the dictionary was supposed to be published in 2006. However, there were technical hitches which saw the draft of the dictionary being submitted to the publishers only in 2009.

In Zimbabwe, a culture of dictionary compilation and use has not been thoroughly developed. Consequently, most of the lexicographic products in the Zimbabwean context come as pioneering projects. In societies with a long history of lexicography, it is easy to identify the gaps that a newly initiated dictionary project is meant to fill within the context of other earlier and previously published dictionary products. In such situations, both the compiler and the target users have a common goal and expectation. The target users' needs are easy to identify and satisfy since the compiler will not be starting a completely new process. However, despite the varying needs of the target users and the difference in the challenges faced by compilers working on different dictionary projects, the target users' needs have to remain a priority. Hartmann (2001: 80) says: "Ultimately all dictionaries are motivated by and judged against the lexical needs of those who consult them."

Emphasis is always laid on the need to address the target users' expectations. Gouws (1993: 29) says: "It is an accepted fact that every dictionary has to be compiled in accordance with specific needs and demands of a well-defined target user." Here the task for the compiler is clearly defined. The parameters for the production of a "perfect" dictionary are delineated. The expectations are that a dictionary must have authority, scholarship and precision (Landau 2001: 6). At the same time, it has to be considered that their expectations differ for various reasons, including the linguistic and the socio-cultural nature of the communities for which the dictionaries are compiled. As a result, each dictionary project may face problems that remain peculiar to it. The SCD team conducted outreach programmes and workshops with the aim of determining the actual needs and expectations of the target users. Primary school teachers, primary school children and interested and knowledgeable parents were consulted during these programmes and workshops. This article discusses the challenges that the team compiling the SCD faced in view of the recommendations given by the target users. The problematic areas that the team had to deal 
with are mainly dialectal representation, tone marking for the purpose of pronunciation, inclusion of international words, the treatment of words deemed culturally taboo and the setting of the back matter.

\section{Dialectal Representation}

Shona has five major dialects namely: Karanga, Zezuru, Ndau, Manyika and Korekore. What the research team gathered from the outreach programmes and workshops was that in the past there has been preferential treatment of the Zezuru and Karanga dialects in the Shona resource books used at primary school level. These two dialects have minimal differences compared to the rest of the dialects. This tended to disadvantage pupils who speak other dialects and it was alleged that there was a high failure rate in Shona examinations among them. Zezuru and Karanga which are more central to the whole Shonaspeaking community are inclined to dominate and the rest of the dialects play a peripheral role. The feeling was that children particularly from Ndau- and Korekore-speaking areas fail to comprehend the vocabulary from the central dialects. Manyika figured less prominently in the debate as it forms a buffer dialect that is in contact with the central dialects and Ndau and Korekore.

Doke (1931: 81) laid down the basic principle that was to be followed in the compilation of Shona dictionaries. He recommended that if a Shona dictionary should be compiled, it has to be as inclusive as possible of words from Zezuru, Karanga, Manyika and Ndau, but for the time being Korekore words have to be admitted sparingly. On the contrary, earlier in his report, on page 9, he shows reservations about the inclusion of Ndau words when he says: "Into their vocabulary is quite a noticeable infiltration of Zulu following the conquest of Gungunhana." This gives the impression that from the time of the defeat of the Ndau, their dialect is no longer pure. As a result Ndau and Korekore cannot without reservations be seriously considered as dialects of Shona. Today the speakers of these dialects are fighting to have their dialects recognized as belonging to the Shona language. A new environmental situation has given them reason to clamour for recognition of their dialects. This is in view of the recommendations by the National Language Advisory Panel of 1998. In the report, Chimhundu et al. (1998: 36) say: "Use of indigenous/local languages should be made mandatory in schools firstly as subjects and later as the medium of instruction." Although Korekore and Ndau are dialects of Shona, their clamour for recognition is similar to that of some Zimbabwean indigenous languages which ought also, according to the report, to be granted the same right as the other languages.

The SCD team had to do strategic research in order to cover the so-called neglected dialects as much as possible. After going through the usual headword selection process in which student research assistants were involved, the team printed a list of the collected headwords. This also saw a substantial number of headwords from these neglected dialects appearing. The next stage 
was to engage the target users, comprising teachers, children and parents. The group of teachers that was engaged firstly had to be speakers of one of these neglected dialects, and secondly had to be teaching in schools in areas where these dialects are spoken. These teachers had the advantage of being speakers and practitioners who were knowledgeable about the problems their pupils face when learning Shona as a subject.

In this way, an additional list of headwords was collected. However, at the same time this strategy also encountered its own problems. As is always the case with groups that feel excluded, there is a tendency to be emotional about their dialects and languages, trying to be as inclusive and exhaustive as possible. Therefore, because of this, a problem surfaced with regard to the many synonymous headwords from the Ndau and Korekore dialects in comparison with the single headwords from the central dialects as shown in (1) and (2) below.

(1)

$$
\begin{aligned}
& \text { central dialects headword } \\
& \text { chikuvauro }
\end{aligned}
$$

guvhu

\section{central dialects headword} gangamwiwe

gangemukange

\section{headwords from Ndau}

chikwa, chichayo chiroo (wooden tool used for flattening the floor)

chikuvhu, chikumvu, mukuvhu (navel)

\section{headwords from Korekore}

fengu, topo, mupagada (type of inedible pumpkin)

madzimba, majochwe (type of ant)

There came plenty of headwords from the excited group of target users who had received the opportunity to show the linguistic ability of their dialects. This resulted in a variety of synonyms and variants to single headwords from the central dialects.

This obviously was a strenuous effort by the speakers to try to prove as much as possible that their dialects have plenty of words that are always omitted. This great number of words posed yet another problem to the dictionary compilers because not all the headwords that were given would be of complete equivalence to the headwords from the central dialects and even amongst the presumed peripheral dialects themselves. This would result in a situation whereby words from the presumed peripheral dialects dominate at the expense of the central dialects. The other problem was how to determine the level of synonymy the terms from the peripheral dialects have among themselves and to those from the central dialects. It seems as if these dialects have a higher level of term productivity than the central dialects.

This touches on the sociolinguistic situation of the people in Zimbabwe. Theirs is a reaction to the colonial history in which the administrative demarcations have become tribal demarcations as well. Dialects become a feature of speech that serves to identify the speaker as a member of a particular speech community, past or present (Landau 2001: 220). This provides the speakers of 
dialects with arguments as they protest at being deliberately excluded where the rule and policy is that the local and indigenous languages have to be empowered without discrimination. The empowerment of languages, as given in the Advisory Panel Report, also means all the dialects have to enjoy equal status. After independence, the policy has been set as a goal to empower the indigenous languages which have always come second to English. The policy sounds all-embracing, implying that there has to be equal treatment of the indigenous languages and implicitly their dialectal varieties. As pointed out by Landau (2001: 219), forms of expression and pronunciation limited to a particular region have long been regarded as objects of contempt and ridicule. This automatically implies that lexical items from those regions are discriminated against when it comes to entering them into the dictionary. This is a feature not peculiar to the Zimbabwean situation only. In general lexicographic works elsewhere, it has also been pointed out that dialects are considered substandard if not plainly incorrect (Landau 2001: 220). The assertion is showing that dialect issues are always problematic. Wherever they feature, they present emotional sentiments. In the Korekore and Ndau situation, their exclusion or selective inclusion leads to protest by speakers who see it as an injustice.

To omit or partly omit some dialect forms such as those from Korekore and Ndau as suggested by Doke, should serve as a warning not to disregard peripheral dialects. However, sidelined dialects will always have their headwords not well recognised in other Shona-speaking areas. As a result, words from these dialects are not quite as familiar to many of the compilers compared to items from the central dialects. The forms of these recognised dialects are always the first to be included in the dictionaries. The central varieties also enjoy being used as the standard, their vocabulary featuring prominently in literary publications which are normally the source for headwords in the dictionaries. Consequently, Korekore and Ndau dialects have always been sidelined in Shona publications including dictionaries that are purported to be comprehensive.

There has to be a policy for handling the dialectal items. As one way of standardising Shona, Doke (1931: 81) recommended that a dictionary has to be a collection of headwords gathered from the different dialects. This has however been found to be a too simplistic way of dealing with the persistent question of unfair treatment of dialects in Shona dictionaries. With every publication there have been allegations by speakers of other dialects that there were no headwords included from their dialects. These groups that maintain that their dialects are not being considered in written Shona also claim that the pass rate in Shona examinations in those areas where Ndau and Korekore are spoken are perpetually low because pupils are always made to study texts representing the central dialects. This is the major reason why target users from those areas were engaged as a reference group. However, with the abundance of headwords coming from these target users, some of them had to be eliminated to balance the dialect ratio in the dictionary. The target users were asked to rank 
the Ndau and Korekore words they had provided in order of preference based on their knowledge of the precise equivalence of these words with the headwords from the central dialects. Eventually the ordering of the above examples was reached as shown under (3) and (4).

(3)

\author{
central dialects headword \\ chikuvauro
}

guvhu

$(4)$ headwords from Ndau

(2) chikwa, (3) chichayo, (1) chiroo (wooden tool used for flattening the floor),

(1) chikuvhu, (3) chikumvu, (2) mukuvhu (navel)

headwords from Korekore

(3) fengu, (2) opo, (1) mupagada (type of inedible pumpkin)

gangemukange

(1) madzimba, (2) jochwe (type of ant)

This ranking was helpful in eliminating headwords from Korekore and Ndau as all those indicated as first were also considered for entry into the dictionary.

\section{Tone marking}

Tone is a fundamental aspect of language. It refers to the distinctive pitch level of a syllable (Crystal 1983: 353). In Shona, the tone contrasts of syllables in words are vital in bringing out the meaning of words. Indicating the tone of words in a dictionary is also important in demonstrating the way words are pronounced. The issue of tone marking became problematic when a recommendation against its inclusion was suggested by the prospective target users during the workshops and outreach programmes. As compilers become well acquainted with dictionary making, some of the practices become routine, usually laid down as standard. ALRI's first two monolingual dictionaries Duramazwi reChiShona (1996) and the advanced Duramazwi Guru reChiShona (2001) did not only include tone markings but went a step further by coining the Shona terms for high and low tone. These are K from kwidza (raise) for high tone and D from dzikisa (lower) for low tone, as shown in example (5) of the headword akapero (acapella music).

$$
\text { akapero DDKD z } 9
$$

The headword has four syllables a+ka+pe+ro. D stands for low tone and $\mathrm{K}$ for high tone. So the first two syllables a and ka marked by DD are low tones, the third syllable pe marked by $\mathrm{K}$ is high tone and the last one ro marked again by $\mathrm{D}$ is low tone. After the tone comes other vital information like $\mathbf{z}$ from zita (noun) which is of class 9, then followed by the definition. In Shona lexicography, tone markings are relatively new grammatical coinages that are being 
standardised not only in the SCD, but also in other ongoing projects that deal with Shona language and grammar.

The target users' position can be understood. The introduction of new elements such as tone marking which gives specialised grammatical information vital to the pronunciation of words is mostly regarded with reservation. The main question arose whether the SCD team had to include information which did not interest the target users. On the other hand it can also be asked if tone marking should be omitted simply because some target users are not fully acquainted with its use. The problem was complicated by the fact that the speakers of the central dialects needed assistance in the pronunciation of the many new headwords from Ndau and Korekore as much as the speakers of these peripheral dialects needed to acquaint themselves with the tone of the headwords from the central dialects.

As a result, the inclusion of tone was considered helpful to users when pronouncing words. It may be argued that children have not yet been exposed to these complicated grammatical aspects such as tone. However, this information may assist the teacher working with the children. A dictionary that is inclusive has an added advantage to those who might need that extra information. The teacher can help pupils extract what is relevant to them. At the same time the availability of a dictionary which has extra details leaves the teacher assisting the pupils with additional information although the pupils may not use it themselves. This does not mean that the suggestions by the target users had to be disregarded completely, but the merit of such suggestions had to be reviewed as well.

As a reference work, a dictionary has many functions. The SCD team agreed that there was need to have the tone marked in the data base and again recommended the idea of indicating tone in the dictionary to the working groups consisting of target users. The admissibility of tone markings in the dictionary were again assessed in the sample headwords and definitions which were taken to the target users during the outreach and seminar programmes. When the same aspects are again brought up for discussion and viewed in print the target users are normally forthcoming with suggestions for improvement. Tone marking was eventually accepted as an essential tool in the dictionary.

\section{International Words}

What have come to be regarded as international words are those ones that have originated in particular languages but are now used across the world in almost every language. At this stage, they have not been adopted in the Shona language yet but because of their specialised sphere of use are always mentioned in Shona texts. Examples of these are words denoting weight, length and scientific and mathematical terms, as demonstrated in the examples under (6). 
(6) weight: kilogramme, tone

length: centimetre, metre, kilometre

scientific and mathematical terms: atom, equation, equator

These and many others are recognised standard terms in many languages. The initial view on the possible inclusion of these terms in the SCD was purist in nature. As they were considered foreign, they were seen as unsuitable for a dictionary meant to strengthen children's communication skills in the Shona language. However, because the purpose of compiling the dictionary was to empower the Shona language, brought some change in perception. The language has to be developed so that it would be able to describe scientific concepts. The target users did not accept the idea of outright adoption but opted for the coinage of "pure" Shona terms. A precedence has already been set before when coinage was attempted in Hannan's (1981) Standard Shona Dictionary which yielded words like dutavanhu (bus), hambautare (motorcar) and bhizautare (bicycle) in an attempt to avoid using English terms. Naturally, when people speak they say bhazi (bus), motokari (motorcar) and bhasikoro (bicycle) which are all adoptives. People hardly use the once prescribed coinages.

Being aware of the fate of some coinages in Hannan's dictionary, the SCD team of compilers argued against their inclusion. These coinages would end up as redundant entries in the dictionary and the terminological gap they were meant to fill would remain open. If its natural behaviour is considered, a language gives preference to adoptives that are close to the source language in spelling and pronunciation. However, there was the difficulty that some of the borrowed headwords had to be adapted to suit the Shona spelling system. The examples of the international words above were entered as shown under (7):

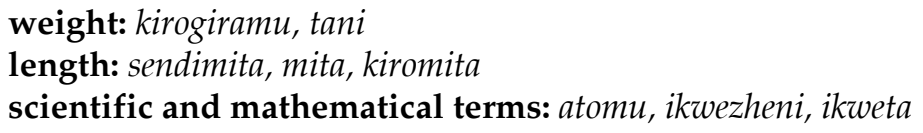

The Shona alphabet does not have the letter $l$ but the trend has been that it can be substituted by $r$, hence the change from the English term kilogramme to kirogiramu. In Shona, the vowel $o$ cannot be realised as /a/ as in the case of the English word tone in which the first syllable sounds like /ta/. The new adoptive for tone is now /tani/. Similarly the initial vowel $e$ in the word equator is realised as /i/, therefore the change to /ikweta/. All syllables in Shona are marked by a vowel, hence the change of the word mitre to / mita/ where it now has the syllables / $\mathrm{mi} /$ and / $\mathrm{ta} /$.

The adoptives had to be adapted to the Shona writing system. This was found to be an important step towards empowering the Shona language, particularly in a book targeted at a group that is at the foundation level of the education system. This will give the target users the confidence to use the language in fields where other languages such as English have always dominated. The target users' creative abilities will be enhanced. This will broaden their view of 
the world in which they, using their mother tongue, can be active participants. The belief is that what has already been initiated will continue and eventually the Shona language will not be void of such important terminology.

\section{Taboo words}

Another category of words that needed special attention was taboo words. Taboo words are known to speakers but avoided in some, most or all forms or contexts of speech (Matthews 1997: 371). Considerations regarding taboo words can be culture-bound. Culture, however, changes, causing the taboo tag given to some lexical elements to be removed partly or wholly. It is important for dictionary compilers to fully know and understand the feelings of the target users on some important aspects of the dictionary they compile. The issue becomes much more complicated when questions arise on whether some aspects are culturally acceptable to be entered into the dictionary. The dictionary compiler has to have a full understanding of the users whom the compilers have sometimes ignored so that there was little appreciation for some dictionary products. The position of target users has to be ascertained in order to avoid criticism of the dictionary product. About the dictionary user, Hartmann (2001: 80) says: "We still know very little about the dictionary user whom several authorities have called the familiar stranger, presumably because we take him for granted without bothering further."

Hartmann's assertion assumes that the participation of the target users in making their recommendations towards the contents of a dictionary may help enhance the lexicographer's insights leading to a lexicographic product that answers the user's needs. The question that has to be answered is whether the shape of a dictionary should be completely determined by the target users. Does the compiler have some authority and power to incorporate new challenges that can help change the society's view of the world? Such challenges were encountered in the compilation of the SCD with regard to taboo words. The target users, particularly the teachers and parents, were clear and adamant that human private parts and some physiological terms would not be acceptable in a dictionary meant for children. According to their view, these children are at the critical stage where there has to be a total induction into their culture. Part of the culture forbids having access to knowledge of these taboo words, particularly by primary school children.

The refusal to enter headwords deemed to be breaching the ethical code of the society is not peculiar to the Zimbabwean situation. All communities at the initial stages of their lexicographic tradition seem to follow the trend of reservations on the inclusion of what is deemed taboo (see Landau $2001: 228$ ). There is the feeling that the exclusion of taboo words contributes towards the upholding of ethical values.

Because the situation of the SCD was found to be rather unique, it brought 
a number of challenges. Firstly, by aiming primary school children as target users, the dictionary belongs to a type of its own in comparison to the earlier publications Duramazwi reChiShona (1996), targeted at ordinary level students and Duramazwi Guru reChiShona (2001), targeted at college and university level students. Secondly, there are new challenges not only to the Zimbabwean society but to societies worldwide that need to be addressed to this age group as a matter of urgency. One channel of doing so is through books such as the SCD. Because the world is changing fast, what society once might have strongly considered taboo might need to be reconsidered in today's world. One of the biggest challenges that have besieged the world is the advent of HIV and AIDS. There is also the problem of the early indulgence in sexual intercourse by today's children and the dangers that go with such activities. There is the rampant problem of child abuse and rape. These and other challenges have resulted in the need to teach and inform children as a precautionary measure about the dangers of the various sexually transmitted diseases and the eventual consequences. All these problems cannot be fully understood if discussed in unclear and veiled language.

In Zimbabwe, the language situation is such that English has been accorded the official status and Shona has always come second to English. This has led to a culture in which anything presumed to contain difficult and foreign concepts should be explained in English. Everything is left to feature in the English texts to which the majority of school-going children eventually have access. However, since English in Zimbabwe is learnt as a second language, there is little consideration at what time or stage in the children's educational development, they will be able to fully comprehend English. This has consequently led to the exclusion and avoidance of vital terms in Shona textbooks. The SCD was caught up in a similar dilemma. As a result, the teachers who have become accustomed to this culture over the years oppose the inclusion of these taboo words in a children's dictionary, their argument being that it will be antisocial to expose children to such terminology.

After serious discussions, it was agreed that some of these presumed taboo words had to be included as long as their role was to give information found to be vital to the children. These are terms specifying the body parts, describing the signs and symptoms of venereal diseases and naming some sexual activities which cannot be avoided mentioning when teaching the children. Examples of such headwords are listed under (8).

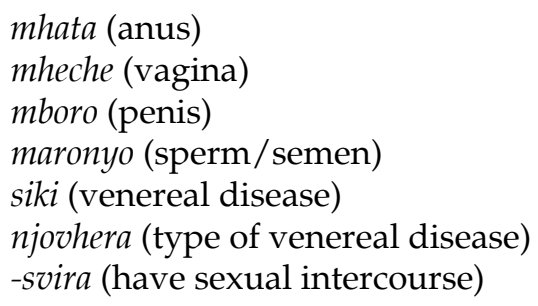


These were allowed into the dictionary because of needs and challenges. However, despite their relatedness to the words under (8), there were some reservations on the inclusion of another group of words which were deemed unnecessary for the level of primary school children. These are common taboo words describing the nature of certain sexual organs or the manner of some sexual activities. Examples of words about which teachers had reservations are given under (9).

(9) beche (big vagina)

zimboro (big penis)

nzvonyo (circumcised penis)

mukodo (sexual intercourse from the back)

mufongo (sexual intercourse from the back)

It was agreed that specimens of normal use should be given for nouns. It was felt that including words meant to give an obscure or indistinct explanation of the mentioned organs and activities would actually destroy the main aim of teaching, and could create confusion and uncertainty in the children that will in reality be contrary to the aim and purpose of the words' inclusion. So the taboo words would have to be selectively entered into the dictionary. Inclusion of some of the vital words will assist in the newly introduced subjects on HIV and AIDS. The children are also being taught issues of human rights in which child sexual abuse would be discussed. Children should know what abuse is and should be able to describe it if the need arises. Because teachers and parents should be able to talk to the children, the vocabulary that was considered to be taboo has to be made normal and familiar by including it in a general dictionary such as the SCD.

\section{Back Matter}

One of the main concerns of a dictionary is to give comprehensive information. A dictionary of the SCD type has to contain information on issues children might not have had a true experience of and direct exposure to in their lives. For example, a child born and bred in town might not be fully aware of aspects that are predominantly rural and vice versa. As a result the dictionary is expected to play an informative role with many aspects reserved for the back matter. As has been pointed out, the SCD project generated much interest among teachers who played a major role as a reference group advising the compiling team. There was also much interest from the community at large who also felt the dictionary would be a useful resource for their children, particularly when writing the Grade 7 Shona examinations. These are vital examinations which need to be passed before children can proceed to secondary level. There have always been complaints from teachers and parents about the 
lack of resource materials for the Shona examinations at primary school level. The idea was to try as much as possible to provide for the different sections of the examinations usually written at this level. So the SCD project was considered to be a major step in compensating for this lack. This resulted in a number of suggestions on additions to be made to the dictionary over and above the general headwords and their definitions. All the additional information could be placed in the dictionary as back matter. It was suggested that this back matter could include a list of people and their professions, a list of animals and their young ones, illustrations of kitchen utensils, a list of common proverbs and idioms and a list of kinship terms. While this would generally be a recommendable idea, it had its own limitations. An example of how this was to be done is shown under (10).

\section{(10) Tete ihanzvadzi yababa (One's aunt is one's father's sister)}

Tezvara ndibaba vomudzinai (One's father-in-law is one's wife's father)

From the first example, the words tete (aunt), hanzvadzi (sister) and baba (father) would have been entered as headwords in the dictionary. Such is also the case with words like tezvara (father-in-law), baba (father) and mudzimai (wife) from the second example. They again appear as repeat entries in the back matter where they, despite being combined in a new context, are in fact a duplication within the same dictionary. Such is also the case with illustrations and all the aspects that were suggested for inclusion in the back matter. A careful selection had to be made to include only those that would bring extra information beyond what could already be found in the headword section. An example of a topographical illustration that was chosen, is a mountain. The illustration would then show gomo (mountain), mawere (cliff), mupata (valley) and bako (cave).

The lexicographer is always contending with the issue of space in the dictionary. At the same time, it has to be understood that the dictionary has its limitations as a reference book. It cannot be the ultimate solution to everything related to examinations. Moreover, as this is a general and not an encyclopaedic dictionary, it was found to be difficult to include all the suggested aspects in the back matter limited by size and detail. Eventually it was resolved that the dictionary could include trimmed lists. However, the compilers had to be careful not to outrightly refuse special requests from the reference group which forms a major component of the target users.

As a compromise it was agreed that some of the requests would actually be better incorporated in school text books. A dictionary was only meant to address problems that usually arise out of the subject matter of text books. It was not meant to provide solutions for these problems and at the same time function as a text book which addresses all aspects of Shona as a school subject. It was hoped that the compilation of the SCD would help generate interest by other relevant participants to write Shona books for primary school level. 


\section{Conclusion}

It is every dictionary compiler's wish to produce a dictionary that fully makes provision for the needs of target users. As a result, it is necessary to consult its prospective target users. The SCD project involved them to a great extent. However, each dictionary project faces challenges of a general nature and at times some which are peculiar to it. This article has discussed those which are peculiar to the SCD, starting with the nature of the target user group which mostly comprised teachers and parents, despite the fact that the real target users are children. Children as a group have to be guided, hence they are mostly represented by the teachers and parents so that their own contribution is minimal.

The article has discussed the discrepancies that in the past occurred in the treatment of Shona dialects. It has looked at the pressure exerted by the speakers of the neglected dialects, showing how the new scenario has impacted on the SCD project, including the problem of excessive headwords that had to be reduced to bring about a balance with other dialects. Dictionary making is also important in introducing and standardising new aspects for the benefit of target users. As a result, the SCD tried to uphold the new phenomenon of marking the tone, which is vital for the pronunciation of headwords. Although target users are not yet comfortable with tone marking, it is hoped that once introduced and maintained as a lexicographic tradition, target users will soon be familiar with it.

This being a pioneering project of a unique nature, it had to confront new challenges. As a result it included some adopted international words. This is an attempt to bring Shona on the same level of communicative ability with other developed languages so that foreign languages need not to be used in discussions dealing with foreign concepts. As the world is changing, this also demands cultural change. Therefore, the once considered taboo words found their way into the SCD. The aim is to enable communication with the children, so resources such as the SCD must have a high information level. For this reason, some additional carefully selected material has been added as back matter to the general dictionary, at the same time taking limitations of space and detail into account. Challenges occur in dictionary making but they can be discussed and overcome in some way or other.

\section{References}

Chimhundu, H. et al. 1998. Report on the Formulation of a National Language Policy. Harare: Ministry of Sport, Recreation and Culture.

Chimhundu, H. (Ed.). 1996. Duramazwi reChiShona. Harare: College Press.

Chimhundu, H. (Ed.). 2001. Duramazwi Guru reChiShona. Harare: College Press.

Doke, C. 1931. Report on the Unification of Shona Dialects Carried Out under the Auspices of the Government of Southern Rhodesia and the Carnegie Corporation. Hertford: Stephen Austin. 
Crystal, D. 1991. A Dictionary of Linguistics and Phonetics. Third Edition. Cambridge: Basil Blackwell.

Gouws, R.H. 1993. Afrikaans Learner's Dictionaries for a Multilingual South Africa. Lexikos 3: 2966.

Hannan, M. 1959. Standard Shona Dictionary. Salisbury: The College Press.

Hartmann, R.R.K. 2001. Teaching and Researching Lexicography. London: Longman.

Landau, S.I. 2001. Dictionaries: The Art and Craft of Lexicography. Second Edition. Cambridge: Cambridge University Press.

Matthews, P.H. 1997. Oxford Concise Dictionary of Linguistics. Oxford: Oxford University Press.

Mpofu, N. et al. (Eds.). 2004. Duramazwi reUrapi neUtano. Gweru: Mambo Press. 